\title{
Historical Review
}

\section{A Historical Analysis of the Relationship Between Encephalitis Lethargica and Postencephalitic Parkinsonism: A Complex Rather than a Direct Relationship}

\author{
Joel A. Vilensky, $\mathrm{PhD},{ }^{1 *}$ Sid Gilman, $\mathrm{MD},{ }^{2}$ and Sherman McCall, $\mathrm{MD}^{3}$ \\ ${ }^{I}$ Department of Anatomy and Cell Biology, Indiana University School of Medicine, Fort Wayne, Indiana, USA \\ ${ }^{2}$ Department of Neurology, University of Michigan School of Medicine, Ann Arbor, Michigan, USA \\ ${ }^{3}$ Department of Clinical Pathology, US Army Medical Research Institute of Infectious Diseases (USAMRIID),
} Fort Detrick, Maryland, USA

\begin{abstract}
Postencephalitic parkinsonism has been considered unique among disorders with parkinsonian features because it is believed to have a unitary etiology associated with the virus that presumably caused encephalitis lethargica. Careful analysis of the historical record, however, suggests that this relationship is more complex than commonly perceived. In most cases, the diagnosis of acute encephalitis lethargica was made post hoc, and virtually any catarrh-like illness was considered to have represented encephalitis lethargica, often after an oral history-taking that was undoubtedly subject to patient recall and physician bias. Also, postencephalitic parkinsonism and oculogyric crises were not
\end{abstract}

recognized as sequelae to encephalitis lethargica until well after other sequelae such as movement disorders and mental disturbances had been identified (see previous paper). We suggest here that the relationship between encephalitis lethargica and postencephalitic parkinsonism is not simplistic, i.e., encephalitis lethargica was not solely responsible for the etiology of postencephalitic parkinsonism, thus aligning the latter with most other parkinsonian disorders that are now believed to have multiple causes. (C) 2010 Movement Disorder Society

Key words: epidemic encephalitis; von Economo's disease; encephalitic parkinsonism

\section{INTRODUCTION}

"In syndromes, anomalies must not be considered mere forme fruste but rather serve as stimuli to question the prevailing paradigm." 1

Encephalitis lethargica (EL) was a polymorphic epidemic disease of the early part of the 20th century that was characterized by von Economo in $1917 .^{2,3}$ Although the cause of the disease remains unknown, it is generally assumed to have had a viral etiology and some clinicians of the time and subsequently linked

*Correspondence to: Joel A. Vilensky, Indiana University School of Medicine, 2101 E. Coliseum Blvd., Fort Wayne 46805, Indiana.

E-mail: vilensk@ipfw.edu

Potential conflict of interest: Nothing to report.

Received 23 April 2009; Revised 17 July 2009; Accepted 30 October 2009

Published online 24 May 2010 in Wiley InterScience (www. interscience.wiley.com). DOI: 10.1002/mds.22908 the disease to the approximately contemporaneous influenza pandemic. ${ }^{4}$ A recent review, however, revealed little evidence supporting this relationship, although the possibility could not be excluded. ${ }^{5}$ Although many aspects of EL remain unknown, there is good evidence that it had multiple sequelae, the most serious of which in adults was postencephalitic parkinsonism (PEP). ${ }^{6}$ PEP received popular attention in the 1973 book, Awakenings, by Oliver Sacks ${ }^{7}$ and the later movie of the same name. We present here and in the companion paper $^{8}$ a detailed historical analysis of the epidemic period suggesting that the relationship between EL and PEP is less definitive, or perhaps more complex, than current belief warrants.

Five factors stimulated our search for evidence that EL and PEP may be less related than currently believed: (1) Casals et al. ${ }^{4}$ thoroughly reviewed the evidence relating parkinsonism to viruses and con- 
cluded that, although viruses may invade the CNS, they rarely, if ever, cause parkinsonism. Consequently, assuming that EL was caused by a virus requires accepting that the EL virus was unique in that it could cause parkinsonism. An alternative explanation is that EL did not directly cause PEP. (2) In the EL/PEP literature, we repeatedly found reports describing patients with PEP who had no prior history of an acute phase of EL (cf. below). Typically these patients were assumed to have had asymptomatic EL (i.e., forme fruste), but we question that assumption. (3) PEP and oculogyric crises (OCs) were not considered as sequelae to EL until well after it was clear that EL resulted in other chronic sequelae, suggesting that perhaps it is not a unitary condition. (4) Initially many clinicians saw little differences between PEP and idiopathic Parkinson's disease (PD). (5) The amyostatic-akinetic (parkinsonian) form of acute EL, which is one of the reasons EL and PEP have been linked, was not universally recognized initially and was considered by some observers to be different symptomatically from PEP.

Factors 3-5 have been addressed in the previous paper of this two-paper set. We showed that by approximately 1924, it was generally accepted that PEP was one of a variety of types of long-term sequelae of EL. Considering the initial diagnostic confusion, however, the data supporting this assertion was muddled. Moreover, we showed in that paper that the "parkinsonian" type of EL was possibly limited temporally and geographically in its presence and therefore may have been a unique variant of EL, casting further doubt on the relationship between EL and PEP.

Here, as in the previous paper, we have incorporated information that was published in all three of the major scientific languages of the period: English, French, and German.

\section{VIRUSES, EL, AND PEP}

Casals et al. ${ }^{4}$ examined the possible relationships between parkinsonism and the following known viruses: California encephalitis, Coxackie virus diseases, Cytomegalovirus infections, Eastern equine encephalitis, herpes virus infection, HIV, infectious mononucleosis, influenza, Japanese encephalitis, lymphocytic choriomenigitis, mumps, Murray valley encephalitis, papoviruses, poliovirus, rubella, rubeola (measles), Russian springsummer encephalitis (European tick-borne encephalitis), St. Louis encephalitis, Varicella (zoster virus), Venezuelan equine encephalitis, and Western equine encephalitis. They concluded, "Encephalitides due to established neurotrophic viruses or to other viruses that may on occasion invade the CNS only rarely produce parkinsonism, and when they do it differs from that seen in EL." They also noted that, although the data on the etiology of EL is consistent with a virus, this is an assumption. These authors thus paradoxically attributed EL to a virus but concluded that viruses do not generally cause the symptomatology associated with EL and PEP. No publications subsequent to this article suggest an alternate view. ${ }^{9}$ Accepting a viral etiology for a parkinsonian disorder is most reasonable when the latter occurs during the acute or convalescent stage of a febrile illness; ${ }^{10}$ it would seem much less likely in the cases of PEP, which occurred years after apparent recovery from EL.

\section{PREVIOUS HISTORIES OF PEP PATIENTS}

In his 1924 monograph, Chronic Epidemic Encephalitis, Wimmer ${ }^{11}$ stated: "Among my own patients, it was only in a minority of cases that I was able to obtain information, which indicated a fairly typical "encephalitis lethargica." Far more frequently there was an indication of a short, common febrile phase, without the encephalitis triad (fever, lethargy, eye symptoms), and which was designated by the physician in charge of the patient, or by the patient himself, sometimes as "influenza," sometimes as "the Spanish disease" (commonly called "the flu')." Wimmer attributed cases that showed no acute symptoms at all to "ambulatory encephalitis."

Many other clinicians of this period, including von Economo, also reported that a varying percentage (in some cases a majority) of their PEP patients had no previous history of an acute phase of EL (Table 1). Krabbe, in $1932,{ }^{25}$ in addition to noting that many cases of EL were originally diagnosed as influenza, also noted the difficulty in distinguishing EL from what has been formerly called multiple sclerosis. Similarly, Corral-Corral and Quereda Rodriguez-Navarro in a 2007 review of chronic EL in Spain ${ }^{32}$ reported that in Galicia there were many PEP cases although there had not been a previous EL epidemic in that city. Similarly, von Economo ${ }^{2}$ noted that there were cities such as Buenos Aires that had a substantial number of PEP cases but no serious EL epidemics. This seems difficult to explain unless one accepted that virtually every case of EL in these cities were forme frustes.

As just noted, the development of PEP in patients without prior EL symptomatology has repeatedly been explained by suggesting that these patients had had asymptomatic EL (forme fruste). This argument appears circular; it assumes EL caused PEP and therefore assumes that if a patient had PEP without any evidence of EL, we must be missing the evidence of EL. 
TABLE 1. Relationships between acute EL, influenza and PEP from epidemic period

\begin{tabular}{|c|c|c|c|c|}
\hline Source & Year & EL* & Influenza** & Comment \\
\hline Drysdale $^{12}$ & 1922 & & & For a few there was no confirmation of an EL phase \\
\hline Levy $^{13}$ & 1922 & & & $\begin{array}{l}\text { ".. The history of the patient shows in this parkinsonian syndrome, with varying } \\
\text { degrees of evidence (our italics) but almost known after research, some } \\
\text { characteristic sign of its encephalitic origin..." }\end{array}$ \\
\hline Parsons et al. ${ }^{14}$ & 1922 & 64 & & $\begin{array}{l}50 \text { other chronic cases did not have a history of acute EL (thus somewhat more } \\
\text { than } 1 / 2 \text { of cases showed distinct EL phase) }\end{array}$ \\
\hline Symonds ${ }^{15}$ & 1923 & & & Many patients with sequelae were not recognized as having an acute phase \\
\hline Naville $^{16}$ & 1923 & & & $\begin{array}{l}23 \text { cases that consisted of postencephalitic sequelae not originally diagnosed as EL; } \\
\text { some were diagnosed as ocular paralysis, some with nothing; assumes that these } \\
\text { patients had rudimentary or abortive EL }\end{array}$ \\
\hline Wimmer ${ }^{11}$ & 1924 & & & Distinct acute phase was apparent only in minority of chronic cases (see text). \\
\hline Cohen $^{17}$ & 1926 & 5 & 7 & $\begin{array}{l}\text { The history for four other PEP cases was considered to be "stroke," and for three, } \\
\text { nothing was listed. }\end{array}$ \\
\hline Hassin and Basoe ${ }^{18}$ & 1926 & 1 & & $\begin{array}{l}\text { Three other cases had neither influenza nor EL; "PEP was associated with syphilis, } \\
\text { head injury, and in cases with no history the patient was considered to have } \\
\text { "paralysis agitans sine agitation." }\end{array}$ \\
\hline Steel $^{19}$ & 1927 & 1 & 1 & $\begin{array}{l}\text { Five other PEP cases had neither influenza nor EL; notes that the hospital } \\
\text { (Scotland) had seen quite a few cases of "postencephalitic syndrome" in last } \\
\text { two years but it has been rare to be able to attribute the disorder to a prior phase } \\
\text { of acute EL; rather, influenza was a much more frequently cited prior disease. }\end{array}$ \\
\hline Young $^{20}$ & 1927 & 29 & 5 & $\begin{array}{l}\text { Five other cases had neither influenza or EL; acute diagnoses ranged from } \\
\text { asymptomatic to appendicitis. }\end{array}$ \\
\hline Parsons $^{21}$ & 1928 & & & $\begin{array}{l}\text { Common finding for acute attack to be mild and ambulatory when previous } \\
\text { histories are carefully examined. }\end{array}$ \\
\hline Hill $^{22}$ & 1929 & & & $\begin{array}{l}\text { "The insidious development of the syndrome (PEP) with no history of an acute } \\
\text { attack." }\end{array}$ \\
\hline von Economo ${ }^{2}$ & 1929 & & & Noted that there were PEP cases with no prior illness \\
\hline Borthwick $^{23}$ & 1931 & & & $\begin{array}{l}\text { "Many of the patients showing typical signs of chronic encephalitis can give no } \\
\text { history of ever having an acute infection, or even an indefinite one." }\end{array}$ \\
\hline Hunter $^{24}$ & 1931 & & & Pertaining to PEP, some patients have no prior symptoms. \\
\hline Krabbe $^{25}$ & 1932 & 16 & 38 & $\begin{array}{l}\text { Six had no preceding illness; } 18 \text { of the } 38 \text { influenza cases were considered } \\
\text { consistent with EL and rediagnosed as EL. }\end{array}$ \\
\hline Hurst $^{26}$ & 1934 & & & $\begin{array}{l}\text { "Some cases had a febrile illness prior to admission and had been diagnosed with } \\
\text { influenza; one occurred after mumps and after ethmoiditis. Others gave no } \\
\text { history of acute illness." }\end{array}$ \\
\hline Solomon et al. ${ }^{27}$ & 1937 & 17 & & $\begin{array}{l}\text { In four additional PEP patients, a history of encephalitis was considered probable } \\
\text { whereas for another } 7 \text { PEPs no history of encephalitis could be ascertained. }\end{array}$ \\
\hline $\mathrm{Neal}^{28}$ & 1942 & 228 & 104 & $\begin{array}{l}26 \text { other cases had some illness that might have been EL; } 149 \text { others gave no } \\
\text { history at all of any illness that seemed to resemble EL; noted that it is entirely } \\
\text { possible in the latter cases that there had occurred an acute phase of the disease } \\
\text { that was undiagnosed as EL. }\end{array}$ \\
\hline Dimsdale ${ }^{29}$ & 1946 & 78 & & $\begin{array}{l}53 \text { other patients resembled PEP in clinical features but had no history of a prior } \\
\text { episode of EL; Dimsdale referred to these cases as "indeterminate } \\
\text { parkinsonism." }\end{array}$ \\
\hline Chavany et al. ${ }^{30}$ & 1951 & & & $\begin{array}{l}\text { "In the greatest number of parkinsonian syndromes that we actually saw at the } \\
\text { time of condition, in subjects young and adult, the proof of initial infection } \\
\text { cannot be given." }\end{array}$ \\
\hline Baruk $^{31}$ & 1953 & & & $\begin{array}{l}\text { One case; first signs of PEP appeared in 1939; no notable antecedent illness is } \\
\text { present in the patient's history }\end{array}$ \\
\hline $\operatorname{Sacks}^{7}$ & 1973 & 11 & 2 & Seven other cases had no documentation of either EL or influenza \\
\hline $\begin{array}{l}\text { Corral-Corral and } \\
\text { Quereda Rodriguez-Navarro } \\
32\end{array}$ & 2007 & 118 & & $\begin{array}{l}22 \text { other cases did not have EL; these data are not limited to PEP (i.e., they include } \\
\text { all postencephalitic syndromes); in some patients there were no prior signs of } \\
\text { EL; also noted that in Galicia in } 1920 \text { there were more than } 100 \text { post- } \\
\text { encephalitic cases whereas almost no cases of EL occurred there (review of } \\
\text { Spanish cases from epidemic period). }\end{array}$ \\
\hline
\end{tabular}

*Number of postencephalitic or PEP cases reviewed whose history showed putative acute EL phase.

**Number of postencephalitic or PEP cases reviewed whose history showed influenza rather than acute EL (or influenza that was then rediagnosed as EL).

In the vast majority of these situations patient histories were based on patient recall, a process that much data have shown to be highly error-prone (cf. below).
Pertaining to the issue of patients with asymptomatic EL, the idea that such persons existed probably developed based on the perplexing issue of EL transmission. 
With some notable exceptions (e.g., Derby girls' school case), ${ }^{33}$ the evidence for person-to-person transmission of EL was weak. ${ }^{1}$ Thus, based on the medical knowledge at the time, researchers concluded that the disease must have been spread by asymptomatic individuals or "healthy carriers;" "Encephalitis lethargica is chiefly conveyed by persons who show no clinical signs of the disease, and in other instances through the agency of mild cases." 14 At this period, our understanding of the processes by which diseases could be spread was limited, e.g., poliomyelitis was thought to be spread by entry of viruses into the nasal passages. ${ }^{34}$ Thus, the entire justification for "healthy carriers" and/ or asymptomatic patients may have been in error.

In contrast to some of the data presented in Table 1, Duvoisin and Yahr in $1965^{6}$ argued that only a small percentage of PEP cases developed in patients who did not have symptomatic EL, citing reports by Ziegler ${ }^{35}$ and Hall. ${ }^{36}$ Ziegler's 1928 study of Mayo clinic patients reported that only about $15 \%$ of PEP cases did not have a history of acute EL. Ziegler's study, however, was not limited to PEP patients but included all of the types of EL sequelae; PEP cases constituted $78 \%$ of this cohort. Ziegler noted that in $22 \%$ of the cases, the acute attack had been diagnosed as influenza but that careful clinical analysis revealed it to be EL. In addition to influenza, the acute attacks had also been initially diagnosed as, "smallpox, measles, mumps, acute rheumatic fever, pleurisy, sore eyes, diarrhea, injury to the head or back, brain tumor, acute appendicitis, typhoid, meningitis, skin rash, pelvic abscess, neuritis, tonsillitis, and so forth."

In his report of 1934, Hall stated, "Out of 480 cases of parkinsonism of which I have full records, about 5 per cent are of this kind, in which there has never been a day's illness which could not be construed (our italics) as the acute infection." Thus, in both of the reports cited by Duvoisin and Yahr, the authors made post hoc diagnoses of EL based on the current manifestations of a disease (cf. above).

Hoehn and Yahr in $1967^{37}$ presented data on 586 cases of parkinsonism of all types who were seen at the Vanderbilt Clinic of the Columbia-Presbyterian Medical Center from 1949-1964. They stated, "In reviewing charts, it was found that many patients, when first seen in the 1930s and 1940s, had been diagnosed as postencephalitic parkinsonism only because the onset of disease occurred at an early age. They had no history of encephalitis lethargica or any other infectious illness, which might be confused with it; they have neither the pathognomonic sequelae (oculogyria and palilalia) nor the other common neurologic seque- lae of encephalitis lethargica. Clinically they are in no way different from patients seen more recently with an early age of onset who are now classified as primary parkinsonism and in this study are classified in that group." These authors also noted a category of parkinsonian patients, indeterminate parkinsonism, in which it was impossible to determine whether the disease was primary or secondary as in PEP, noting in particular that the retrospective diagnosis of EL may have been in error. Thus, these authors also expressed doubts about the post hoc diagnoses of EL during the epidemic period.

\section{INFLUENZA AS EL}

There have been multiple recent reports-based on both historical and molecular data-which have cast influenza as a very unlikely cause of the EL epidemic (see reviews by Reid et al.; McCall et al.; Foley) ${ }^{5,38-41}$ although it could not be ruled out. Despite this view, for patient histories, as evidenced by Table 1 and above, episodes of influenza have been repeatedly rediagnosed as EL to justify a diagnosis of PEP. There is little doubt that some cases of influenza and presumably other conditions were misdiagnosed as EL (Table 2). Accordingly, the Spanish influenza was often reported to have neurologic signs and symptoms that were identical to EL (e.g., diplopia, ptosis, paralyses, pareses, chorea, myoclonus, psychoses, etc.; Table 2); thus, how do we know whether the patients really had EL or influenza, or both (cf. below). Ordway in his 1920 report on the neurologic complications of influenza at Boston City Hospital noted these neurologic disorders were "postinfluenzal" complications, i.e., they had the same relationship to influenza as PEP to EL, and he reported one case of "paralysis agitans" that had an "indeterminate" relationship to the preceding influenza. ${ }^{48}$ In their 1976 review of Parkinson's disease in Finland, Marttila and Rinne ${ }^{52}$ specifically stated that in differentiating PD from PEP, a history of Spanish influenza was not considered equivalent to encephalitis.

Undoubtedly, part of the problem surrounding this issue is that the diagnosis of EL was subjective and imprecise. Accordingly, some clinicians at the time considered it markedly overdiagnosed. ${ }^{53}$ This is perhaps best exemplified by Hirsch, who in $1920^{54}$ asked, "What at the moment is not encephalitis lethargica?" Thus, the rediagnosis of influenza episodes as EL reflects this imprecision, but by the same token, if the diagnosis was so imprecise, how is it possible to define a relationship between EL and PEP? Neal et al. ${ }^{55}$ noted 
TABLE 2. EL-like Complications of the Spanish influenza

\begin{tabular}{|c|c|c|}
\hline Reference & Year & Nervous complications of influenza that resemble EL symptomatology \\
\hline Harris $^{42}$ & 1919 & $\begin{array}{l}\text { "There is no acute malady after which disturbance of the nervous system is so frequent as after influenza, } \\
\text { and none that has such varied nervous sequelae;" "There may be ptosis, paralysis of the external ocular } \\
\text { muscles or even complete third nerve palsy," (p. 93); reported that paraesthesias of all sorts have been } \\
\text { described as sequelae, including pins and needles sensation, vague pains, numbness, hyperaesthesia, etc. } \\
\text { And, "there is scarcely a nerve twig, or nerve trunk, that has not been known to suffer from influenza, } \\
\text { with resulting local tenderness and trophic symptoms of skin or muscle persisting for variable periods;" } \\
\text { also epilepsy can occur }\end{array}$ \\
\hline Savage ${ }^{43}$ & 1919 & Influenza of all the infectious diseases is the most likely to be followed by mental disorder \\
\hline Clark $^{44}$ & 1919 & Epilepsy \\
\hline Nonne $\mathrm{H}^{45}$ & 1919 & Bulbar paralysis \\
\hline Alexander ${ }^{46}$ & 1919 & $\begin{array}{l}\text { Published in British Medical Journal, "Cases resembling encephalitls lethargica occurring during the } \\
\text { influenza epidemic;" noted influenza cases, headache, mental lethargy, facial paralysis, nystagmus, } \\
\text { diplopia, unconsciousness, hemiparesis, pharyngeal paralysis, mental lethargy; suggests lesions similar to } \\
\text { EL }\end{array}$ \\
\hline Guillain and Libert ${ }^{47}$ & 1920 & Paralysis of the serratus anterior \\
\hline Ordway 48 & 1920 & Neuroses, neuritis, hemiplegia, encephalitis, chorea \\
\hline Abrahams $^{50}$ & 1922 & $\begin{array}{l}\text { Recorded several cases of transient Bell's palsy and saw two cases of unilateral posterior thoracic neuritis } \\
\text { with paralysis of the serratus anterior; one directly followed an acute attack of influenza, the other } \\
\text { appearing a few weeks after convalescence; stated that a high percentage of the more serious cases, } \\
\text { whether fatal or not, showed marked involuntary jerkings and twitchings of one limb or of the head and } \\
\text { neck or of one side of the abdomen or of the back }\end{array}$ \\
\hline Boenninghaus $^{51}$ & 1924 & $\begin{array}{l}\text { Described three cases of unilateral pharyngeal paralysis following influenza; in the first, the involvement of } \\
\text { the pharynx was an isolated phenomenon; in the second, it was associated with facial paralysis on the } \\
\text { same side; and in the third with paralysis of the tongue, palate, and vocal cord of the same side; } \\
\text { dysphagia was moderate in degree, but it was impossible to swallow solids without taking some fluid } \\
\text { afterwards; the diagnosis in each case was made by examination of the pharynx on phonation, when the } \\
\text { posterior pharyngeal wall was seen to be drawn to the normal side. }\end{array}$ \\
\hline
\end{tabular}

that a rather large percentage of their 450 cases of EL had previously suffered from some defect or from an acute infection of the CNS prior to developing EL and that this might be responsible for their sequelae.

\section{PATIENT RECALL}

It is likely that in many and, perhaps, most situations pertaining to EL/PEP, the diagnosis of a previous illness such as EL was based on patient recollection. It seems likely that an analogous situation to EL/PEP exists in Gulf War syndrome.

Similar to EL, Gulf syndrome lacks a concise case definition and has notoriously nonspecific symptoms. It has many features suggesting recall bias; Gulf veterans report all symptoms more frequently than military controls. Practically every outcome and exposure surveyed have statistically significant associations. ${ }^{56-58}$ Consistency of recall after 2 to 4 years is only modest, with kappa values mostly from 0.35 to $0.55 .^{59}$ Gulf war veterans with improving health perception recall fewer wartime health hazard exposures over time, whereas those with worsening health perception recall new wartime health hazards over time. ${ }^{59}$ Survey participation rates are consistently 5$10 \%$ higher among Gulf war veterans than military controls $^{57}$ and linkage occurred between news stories and subsequent exposure claims. ${ }^{60}$ Remarkable incongruities occur in recall by veterans deployed only during the precombat Desert Shield phase. Twelve percent claim exposure to the nerve agent antidote pyridostigmine, 22\% claim exposure to SCUD alarms, 5\% to SCUD attacks, and $28 \%$ exposure to chemical weapons, all before these exposures actually occurred. ${ }^{61}$

Recall bias is inherent in brain storage and retrieval. ${ }^{62}$ Identified factors include availability, saliency, recency, and aggregation. Three more aspects of bias seem particularly relevant to the PEP situation. These are state bias in which depressed people recall negative information; effort after meaning, whereby post hoc modifications of events occur that conform to 
subsequent events; and rumination bias, wherein people with diseases think more intensely about prior exposures than healthy individuals. ${ }^{60}$

Such flawed recall produces profound research biases. Retrospective studies exaggerate the placebo effect up to fivefold. ${ }^{62}$ Head injury patients underestimate their symptoms preinjury, thereby increasing apparent postconcussion syndrome. ${ }^{63}$ Mothers of malformed infants retrospectively increase their reported use of medications in pregnancy. ${ }^{64}$ This increases the reported congenital malformation rate fourfold for itraconzole $^{65}$ and 7.6-fold for oral contraceptives. ${ }^{66}$

Reports of EL and PEP are all clinical case series. They are unblinded and retrospective. They lack control groups and are susceptible to interviewer bias. Physicians often redirect patient histories into narrow yes/no questions. ${ }^{67}$ Questions of this structure leave out the "I don't know" response, increasing intrusion errors. ${ }^{68}$ Repeated questioning, as would occur in chronic conditions, can increase reported exposures by $13 \%{ }^{69}$

Patient oral histories are more accurate for welldefined chronic conditions than for less-defined conditions. $^{70}$ Whereas PEP may be the former, delayed recall of a transient attack of EL is not. Clinical diagnosis based on ex post facto clinical interview is a flawed procedure. For example, in an adult follow-up study of childhood Attention Deficit Hyperactivity Disorder the positive predictive value of such a retrospective diagnosis was only $27 \% .^{70}$ Retrospective clinical diagnosis of EL without contemporary medical records or a sound case definition is likewise suspect.

\section{CONCLUSIONS}

Although we question here the foundation supporting the purported relationship between EL and PEP, we want to emphasize that we do not negate the existence of either. EL was undoubtedly overdiagnosed but its independent identification by well-regarded clinicians in many different countries leaves little doubt that it was a distinct nosological entity. Rather, our purpose in these two articles has been to demonstrate that the currently perceived relationship between EL and PEP, i.e., that an episode of EL inevitably led to PEP, is not consistent with ALL or even most of the literature from the epidemic period. We suggest that for various reasons (language, reputations of individuals, etc.) a particular view became embedded in neurologic thinking and has not been challenged since that time.

Table 1 demonstrates that the accepted relationship between EL and PEP, to a large extent, was based on post hoc diagnoses in which influenza as well as many other conditions were considered to have been EL. Josephine Neal, who supervised the vaccine trials for EL and the writing of four massive surveys of the literature on EL, ${ }^{71}$ stated in the final 1942 volume, "the range of symptomatology in acute encephalitis lethargica is so wide that often the diagnosis can be made only with difficulty and occasionally not with certainty." 28 Thus, making a diagnosis at the time the patient was ill was precarious; making a post hoc diagnosis seems unjustified.

In addition, we have demonstrated that during the epidemic period there was great confusion as to how EL, PEP and PD related to each other. ${ }^{8}$ An etiologic relationship was presumed between EL and PEP notwithstanding the absence of any reliable biologic data on the cause of either. We have also showed that, based on published symptomatology and sequelae, there is almost as much justification for associating the Spanish influenza with PEP as for associating EL with PEP. Furthermore, we have proposed that patient recall/physician bias was probably highly influential (i.e., a self-fulfilling prophecy) in the presumptive relationship between EL and PEP.

For this review, we have considered EL to have begun in Europe in Vienna with von Economo's $1917^{2}$ characterization of the syndrome. However, there are earlier (1916) reports of EL on the French warfront ${ }^{72}$ and even earlier from Romania. ${ }^{28}$ Souques $^{73}$ published a paper in 1922 that was titled, "Retrospective diagnosis of encephalitis lethargica in a case of Parkinson's disease lasting 12 years," suggesting that a patient had EL in 1910 that caused her current PD (PEP). More interesting, because EL is believed to have spread from East to West, are a few sporadic U.S. cases as early as 1910 . For example, the 1929 Matheson Commission Report ${ }^{74}$ described a U.S. case of a two-year old who in 1912 appeared to have acute EL that resulted in his being diagnosed with chronic EL in 1928. If these cases are truly EL, then the nonrecognition of PEP until 1920 is even more surprising. On the other hand, Brusa and Pramstaller $^{75}$ examined more than 1000 articles from the neurological literature pertaining to parkinsonism between 1850 and 1916 and described three cases that they considered "atypical parkinsonian cases," from 1895, 1905, and 1909. All three lacked a tremor and the authors concluded that, "clinical syndromes characterized by the presence of extrapyramidal, pseudobulbar, ocular symptoms, and the absence of tremor were also present in the preencephalitic era." These reports are at least suggestive of the presence of PEP before the definitive existence of EL. 
The most obvious criticism of our approach is, if it was not EL, then what caused PEP? Our response is that we do not dispute a role for EL in PEP. EL indeed likely contributed to the development of PEP in most, but perhaps not in all, cases, and there is no definite evidence to indicate that all subjects who developed EL subsequently developed PEP. It is also unclear whether all PEP patients had experienced EL. Similar to the current view pertaining to virtually every other parkinsonian disorder, the development of PEP may have depended upon a complex interaction of environmental (perhaps EL and/or influenza) and predisposing (presumably genetic) factors. The importance of casting doubt on the commonly perceived one-to-one ELPEP relationship is that, if negated, PEP aligns with other parkinsonian disorders in term of causation and in this manner perhaps allows for a more unified approach to understanding the pathophysiology of all of these disorders.

Acknowledgment: Support for this research was provided by the Sophie Cameron Trust (www.thesophiecamerontrust. org.uk). Ms. Hope Owens provided all of the French translations, and Dr. Paul Foley and Mr. Kris Kallmeyer provided the German translations. Mr. Richard Steele and two reviewers provided constructive criticism on prior versions of this manuscript. Drs. Roger Duvoisin, John Steele, and Howard Kushner provided important insights that contributed to our development of these articles.

\section{REFERENCES}

1. Kushner HI, Bastian JF, Turner CH, Burns JC. Rethinking the boundaries of Kawasaki disease. Perspect Biol Med 2003;46: 216-233.

2. Von Economo C. Die encephalitis lethargica, ihre Nachkrankheiten und ihre Behardlung, Berlin: Urban \& Schwarzenberg; 1929. 251 pp (published in English in 1931 [Encephalitis lethargica: Its sequelae and treatment] translated by Newman, K.O. London: Oxford University Press; 1931; 200 pp).

3. Von Economo C. Encephalitis lethargica. Wiener Klin Wochenschr 1917;30:581-585.

4. Casals J, Elizan TS, Yahr MD. Postencephalitic parkinsonism-a review. J Neural Transm 1998;105:645-676.

5. Mccall S, Vilensky J, Gilman S, Taubenberger JK. The relationship between encephalitis lethargica and influenza: a critical analysis. J Neurovirol 2008;14:177-185.

6. Duvoisin RC, Yahr MD. Encephalitis and parkinsonism. Arch Neurol 1965;12:227-239.

7. Sacks O. Awakenings. New York: HarperCollins Publishers; 1973. $408 \mathrm{p}$.

8. Vilensky JA, Gilman S, McCall S. Does the historical literature on encephalitis lethargica support a simple (direct) relationship with postencephalitic parkinsonism? Mov Disord.

9. Litvan I, Halliday G, Hallett M, et al. The etiopathogenesis of Parkinson disease and suggestions for future research. Part I. J Neuropathol Exp Neurol 2007;66:251-257.

10. Lees AJ. Unresolved issues relating to the shaking palsy on the celebration of James Parkinson's 250th birthday. Mov Disord 22: S327-S334.
11. Wimmer A. Chronic epidemic encephalitis. London: William Heinemann; 1924. 335 p.

12. Drysdale HH. Parkinson's disease as sequelae to lethargic encephalitis. Ohio State Med J 1922;842-849.

13. Levy G. Contribution A l'etude des manifestations tardives de L'encephalite epidemique, MD Thesis, Faculte De Medecine De Paris, 1922. 312 p.

14. Parsons AC, Macnalty AS, Perdrau JR. Public health and medical subjects report on encephalitis lethargica: being an account of further enquiries into the epidemiology and clinical features of the disease; including an analysis of over 1,250 reports of cases notified in England and Wales during 1919 and 1920, together with a comprehensive bibliography of a subject. Reports on Public Health and Medical Subjects. No. 11. London: His Majesty's Stationery Office; 1922.344 p.

15. Symonds CP. Critical review: encephalitis lethargica. Quart J Med 1921;14:283-308.

16. Naville F. Sequelae of epidemic encephalitis. Rev Med Suisse Roman 1923;43:1-27.

17. Cohen MJ. Some sequelae of encephalitis lethargica. Med J S Afr 1926;22:139-144.

18. Hassin GB, Bassoe PA. Parkinsonian states: clinico-pathologic studies. Arch Neurol Psychiatr 1926;15:218-238.

19. Steel JP. The onset of post-encephalitic parkinsonism. Edinb Med J 1927;34:231-234.

20. Young AW. A clinical analysis of an extrapyramidal syndrome; paralysis agitans and postencephalitic parkinsonism. J Neurol Psychopathol 1927;8:9-18.

21. Parsons AC. Report of an inquiry into the after-histories of persons attacked by encephalitis lethargica. Reports on Public Health and Medical Subjects, No. 49. London: His Majesty's Stationery Office; 1928. 179 p.

22. Hill TR. Postencephalitic parkinsonism as a chronic infection. J Neurol Psychopathol 1929;9:337-346.

23. Borthwick GA. The sequelae of epidemic encephalitis. Clin J 1931;60:510-514, 521-524.

24. Hunter C. The late sequelae of encephalitis lethargica and of influenza. Can Med Ass J 1931;24:828-830.

25. Krabbe KH. The initial stages of the parkinsonian forms in chronic epidemic encephalitis. Acta Psychiatr Neur 1932;7:317-337.

26. Hurst JH. The relationship of influenza and epidemic encephalitis. Med Bull Vet Adm 1934;11:110-131.

27. Solomon P, Mitchell R, Prinzmetal M. The use of benzedrine sulfate in postencephalitic Parkinson's Disease. JAMA 1937;108: $1765-1770$.

28. Neal JB. Encephalitis: a clinical study. New York: Grune and Stratton; 1942. 563 p.

29. Dimsdale H. Changes in the parkinsonians syndrome in the twentieth century. Q J Med 1946;5:155-170.

30. Chavany J, Bogaert L, Godlewski S. Syndrome of rigidity with axial predominance with perturbation des automatismes ocul-palpebraux d'origine encephalitique. La Presse Medicale 1951;59: 958-962.

31. Baruk H. Postencephalitic parkinsonism with hallucinations treated by lobotomy. Rev Neurol 1953;88:191-196.

32. Corral-Corral I, Quereda Rodriguez-Navarro C. Sindromes postencefaliticos en la literatura medica espanola. Rev Neurol 2007; 44:499-506.

33. MacNalty AS. Report on outbreak of encephalitis lethargica in a girls' home. Great Britain Ministry of Health: On the State of the Public Health; 1919. pp 357-368.

34. Netter A. Etiologie et prohylaxie de l'encephalite lethargique; declaration obligatoire. Bull Acad med 1921;85:278-298.

35. Ziegler LH. Follow-up studies on persons who have had epidemic encephalitis. JAMA 1928;91:138-141.

36. Hall AJ. Prognosis and treatment of chronic epidemic encephalitis. Practitioner 1934;133:26-36.

37. Hoehn MM, Yahr MD. Parkinsonian onset, progression and mortality. Neurology 1967;17:427-442. 
38. Reid AH, Mccall S, Henry JM, Taubenberger JK. Experimenting on the past: the enigma of von Economo's encephalitis lethargica. J Neuropathol Exp Neurol 2001;60:663-670.

39. Foley PB. Encephalitis lethargia and influenza. I. The role of the influenza virus in the influenza pandemic of 1918/1919. J Neural Transm 2009;116:143-150.

40. Foley PB. Encephalitis lethargica and the influenza virus. II. The influenza pandemic of 1918/19 and encephalitis lethargica: epidemiology and symptoms. J Neural Transm 2009;116:1285-1308.

41. Foley PB. Encephalitis lethargica and the influenza virus. III. The influenza pandemic of 1918/19 and encephalitis lethargica: neuropathology and discussion. J Neural Transm 2009;116:13091321.

42. Harris W. The nervous system in influenza. Practitioner 1919; cii: 89-100.

43. Savage GH. The psychoses of influenza. Special Influenza Number, Part I. Practitioner 1919;102:36.

44. Clark LP. Influenza and epileptiform attacks. JAMA 1919;73:1767.

45. Nonne M. Aerzlicher verein, offizielles protokoll. [Official minutes of the Medical Association, Hamburg]. Dtsch Med Wochenschr 1919;27:1038-1039.

46. Alexander JB. Cases resembling epidemic encephalitis occurring during the influenza epidemic. BMJ 1919;1:794-795.

47. Gullian G, Libert E. Paralysie isolee du muscle dentele consecutive a la grippe le signe du crupe sus-claviclaire. Ann Med 1920; 383-391.

48. Ordway MD. Report of neurological sequelae of influenza in the Boston City Hospital Neurological Outpatient Department from July 1918 to July 1919. Boston Med Surg J 1920;182:194-200.

49. Whale HL. Influenza: the complications affecting the throat, nose and ear. In: Crookshank FG, editor. Influenza: essays by several authors. London: William Heinemann Ltd; 1922. pp 406-432.

50. Abrahams A. Influenza: some clinical and therapeutic considerations. In: Crookshank FG, editor. Influenza: essays by several authors. London: William Heinemann Ltd; 1922. pp 314-350.

51. Boenninghaus. Ueber latent Schwäche des Gaumensegels nach 'Grippeenzephalitis' und ihren Nachweis durch Herunterdrücken des Zungengrundes. Dtsch Med Wochenschr 1924;6:1472-1473.

52. Marttila RJ, Rinne UK. Epidemiology of Parkinson's disease in Finland. Acta Neurologica Scand 1976;53:81-102.

53. Ford FR. Diseases of the nervous system in infancy, childhood and adolescence. Springfield, IL: Charles C. Thomas; 1937. $353 \mathrm{p}$.

54. Hirsch C. Zur vergleichenden pathologie der enzephalitis nebst kritschen bermekungen zur encaphalitis lethargic (epidemica)diagnose. Berl Klin Wochesnschr 1920;57:605-607.

55. Neal JB, Jackson HW, Appelbaum E. A study of four hundred and fifty cases of epidemic encephalitis. Am J Med Sci 1925; 170:708-722.

56. Unwin C, Blatchley N, Coker W, et al.. Health of UK servicemen who served in Persian gulf war. Lancet 1999;353:169-178.

57. Hotopf M, David A, Hull L, Ismail K, Unwin C, Wessley S. Role of vaccinations as risk factors for ill health in veterans of the Gulf war: cross sectional study. BMJ 2000;320:363-367.
58. Hotopf M, Wessely S. Can epidemiology clear the fog of war? Lessons from the 1990-91 Gulf War. Int J Epidemiol 2005;34: $791-800$

59. Wessely S, Unwin C, Hotopf M, Hull L, Ismail K, Nicolaou V, David A. Stability of recall of military hazards over time. Evidence from the Persian Gulf War of 1991. Br J Psychiatry 2003; 183:314-322.

60. Sackett L. Bias in analytic research. J Chronic Dis 1979;32: 51-63.

61. McCauley LA, Joos SK, Spencer PS, Lasarev M, Shuell T. Strategies to assess validity of self-reported exposures during the Persian gulf war. Portland Environmental Hazards Research Center. Environ Res 1999;81:195-205.

62. Gendreau M, Hufford MR, Stone A. Measuring clinical pain in chronic widespread pain: selected methodological issues. Best Pract Res Clin Rheumatol 2003;17:575-592.

63. Ferguson RJ, Mittenberg S, Barone DF, Schneider B. Postconcussion syndrome following sports-related head injury: expectation as etiology. Neuropsychology 1999;13:582-589.

64. Werler MM, Pober BR, Nelson K, Holmes LB. Reporting accuracy among mothers of malformed and nonmalformed infants. Am J Epidemiol 1989;129:415-421.

65. Rockenbauer M, Olsen J, Czeizel A, Pedersen L, Sorensen H; EuroMAP Group. Recall bias in a case-control surveillance system on the use of medicine during pregnancy. Epidemiology 2001; 12:461-466.

66. Beckman HB, Frankel RM. The effect of physician behavior on the collection of data. Ann Intern Med 1984;101:692-696.

67. Pezdek K, Sperry K, Owens SM. Interviewing witness: the effect of forced confabulation on event memory. Law Hum Behav 2007;463-478.

68. Fricker D, Reardon E, Spektor D, et al. Pesticide use during the gulf war: a survey of gulf war veterans. Natl Defense Res Inst 2000. Available at: http://www.gulflink.osd.mil/library/randrep/ pesticides_survey/.

69. Kehoe R, Wu SY, Leske MC, Chylack LT. Comparing selfreported and physician-reported medical history. Am J Epidemiol 1994; 139:813-818.

70. Mannuzza S, Klein RG, Klein DF, Bessler A, Shrout P. Accuracy of adult recall of childhood attention deficit hyperactivity disorder. Am J Psychiatry 2002;159:1882-1888.

71. Kroker K. Epidemic encephalitis and American neurology, 19191940. Bull Med Hist 2004;78:108-147.

72. Cruchet R. Quarante cas d'encephalomyelite subaigue. Bullins Soc Med Hop Paris 1917;3:614-616.

73. Souques MA. Rapport sur les syndromes Parkinsoniens. Rev Neurol 1922;37:534-573.

74. Darrach W, Emerson H, Gay FP, et al., editors. Epidemic encephalitis. Etiology, epidemiology, treatment. Report of a survey by the Matheson Commission. New York: Columbia University Press; 1929. 849 p.

75. Brusa A, Pramstaller PP. Ante litteram description of atypical parkinsonian cases. Neurol Sci 2000;21:407-409. 